\title{
PENJATUHAN PIDANA ATAS PENYALAGUNAAN NARKOTIKA GOLONGAN 1 PASAL 114 AYAT(1) UNDANG-UNDANG NOMOR 35 TAHUN 2009 TENTANG NARKOTIKA (Studi Putusan Nomor : 139/Pid.Sus/2016/PN.Grs)
}

\author{
Nafisah 1, Abdul Basid 2 \\ 1. Karyawan Notaris \\ 2. Dosen Fakultas Hukum Universitas Gresik
}

\begin{abstract}
ABSTRAK
Penelitian ini dilatar belakangi oleh fenomena peredaran dan penyalahgunaan narkotika yang semakin hari kian meningkat dan berdampak bagi kehidupan soial, budaya, ekonomi dan politik. Layaknya sebagai budaya bangsa, bahkan putusan hakim pun tak memberikan efek jera terhadap pelaku penyalahgunaan narkotika. Penegakan hukum yang diberikan pada hukum positif adalah dengan jalan memberikan hukuman yang berat yang bersifat in abstracto bukan in concreto berdasarkan pertimbangan-pertimbangan hukum yang dibuat oleh Hakim. Lain halnya hukuman tersebut yang memiliki tata aturan dan dasar pertimbangan sendiri dalam menjatuhkan hukuman terhadap tindak pidana penyalahgunaan narkotika. Fokus penelitian dalam skripsi ini adalah (1) Bagaimana penerapan hukum pidana materiil terhadap tindak pidana penyalahgunaan narkotika golongan 1 berdasarkan Undang-Undang Republik Indonesia Nomor 35 Tahun 2009 tentang Narkotika ? (2) Bagaimana pemidanaan terhadap penyalagunaan Narkotika golongan 1 pada putusan Nomor 130/Pid.Sus/2016/PN.Gsk?

Adapun yang menjadi tujuan penelitian ini adalah Untuk mengetahui putusan hakim dan dasar pertimbangan hakim dalam perkara nomor : 130/Pid.Sus/2016/PN.Gsk terhadap tindak pidana penyalahgunaan narkotika golongan I di Pengadilan Negeri Gresik serta mengkaji hukum islam terhadap pelaksanaan putusan nomor : 130/Pid.Sus/2016/PN.Gsk.

Dalam penelitian ini digunakan metode observasi, wawancara dan dokumentasi. Observasi digunakan untuk memudahkan peneliti dalam melakukan analisis penelitian dengan melibatkan diri secara lansung mengamati proses persidangan. Sedangkan wawancara dan dokumentasi digunakan untuk menggali data yang lebih spesifik terkait dengan dasar pertimbangan hakim, putusan hakim dalam kasus pidana tersebut, sarana prasarana dan dokumen instansi.

Hasil penelitian menunjukkan bahwa putusan majelis hakim nomor 130/Pid.Sus/2016/PN.Gsk menyatakan terdakwa secara sah dan bersalah menggunakan narkotika Golongan I dengan hukuman penjara selama 3 bulan. Hakim dalam menjatuhkan putusan dengan mencari kebenaraan formil dan materiil selama dipersidangan yang dijadikan dasar dalam pertimbangan Hakim yakni berupa alat bukti sesuai dengan Pasal 184 ayat (1) KUHP (keterangan saksi, keterangan ahli, surat, petunjuk, keterangan terdakwa) dan barang bukti atas tindak pidana, serta dakwaan dan tuntutan penuntut umum. Putusan penjara dalam hukum positif ini.
\end{abstract}

Kata Kunci : Putusan hakim, penyalahgunaan Narkotika Golongan I

\section{PENDAHULUAN}

\subsection{Latar Belakang Masalah}

Pembangunan Nasional tidak bisa lepas

dari kehidupan manusia sebagai mesin utama

penggeraknya. Sumber daya manusia menjadi hal yang sangat penting dalam pembangunan karena suatu pembangunan tidak akan bekerja tanpa adanya manusia yang berkualitas. Oleh karena itu pembangunan sumber daya manusia menjadi tugas utama yang harus digarap, karena dengan 
meningkatnya kualitas sumber daya manusia Indonesia menjadikan modal yang sangat penting untuk berkompetisi dalam era globalisasi saat ini.

Hukum pidana yeng lebih baik dan manusiawi kelak di Indonesia. Sejalan pula dengan keinginan kuat untuk mewujudkan suatu penegakan hukum (law enforcement) yang lebih adil terhadap setiap pelangaran hukum pidana dalam era reformasi ini. $^{1}$ Narkotika dan psikotropika merupakan obat atau bahan yang bermanfaat di bidang pengobatan, pelayanan kesehatan, dan pengembangan ilmu pengetahuan, dan pada sisi lain dapat menimbulkan ketergantungan yang sangat merugikan apabila dipergunakan tanpa pengendalian, pengawasan yang ketat dan seksama. ${ }^{2}$

Zat yang terkandung dalam narkoba akan mengubah perasaan dan cara pikir user seperti mendapatkan suasana hati yang tenang, gembira dan rasa bebas. Stress menjadi hilang dan khayalan seorang user narkoba akan meningkat. Zat yang terkandung dalam narkoba bias menghasilkan perasaan yang serba bisa/ego dengan mengubah susunan biokimiawi molekul sel otak pada system Limbus (bagian otak yang bertanggung jawab atas kehidupan perasaan, dimana dalam Limbus ini terdapat Hipotalamus, yaitu pusat kenikmatan pada otak) yang disebut neuro-transmitter. ${ }^{3}$

Obat terlarang, substansi kimia yang mengganggu keberfungsian psikologis dan fisiologis, telah berabad abad digunakan

\footnotetext{
${ }^{1}$ Teguh Sulistia dan Aria Zurnetti, Hukum Pidana : Horizon Baru Pasca Reformasi, Cet. 6, PT RajaGrafindo Persada, Jakarta, 2012, h. 1-2.

${ }^{2}$ Muhammad Yamin, Tindak Pidana Khusus, Pustaka Setia, Bandung, 2009, h. 163.

${ }^{3}$ Sujono dan Bony Daniel, komentar \& pembahasan Undang-Undang Nomor 35 Tahun 2009 tentang Narkotika, Cet. 1, Sinar Grafika, Jakarta, 2011, h. 5.
}

diberbagai kebudayaan sebagai stimulan atau depresan untuk ulasan medis,social, dan sering kali religi opium dipercaya telah ditemukan pada masa neolitik dan telah digunakan oleh para tabib zaman dahulu seperti Hippocrates dan gales. Opium yang merupakan bahan dasar dari turunan lain seperti morfin dan heroin, pertama kali dikenalkan dalam skala besar kepada dunia oleh para pedagang turki sekitar abad ke-8 atau $9 \mathrm{M}$ dan merupakan salah satu barang dagangan perdagangan Eropa pada abad ke-16 dan pada satu titik memberikan hampir setengah dari pemasukan pemerintah kolonial. ${ }^{4}$

Peredaran gelap narkotika dan prekusor narkotika adalah setiap kegiatan atau serangkaian kegiatan yang ditetapkan sebagai tindak pidana narkotika dan prekusor narkotika penyalahgunaan narkotika. $^{5}$

Narkotika merupakan salah satu obat yang diperlukan dalam dunia pengobatan, demikian juga dalam bidang penelitian untuk tujuan pendidikan, pengembangan ilmu dan penerapannya. Meskipun ada bahayanya, namun masih dapat dibenarkan penguna narkotika untuk kepentingan pengobatan dan atau tujuan ilmu pengetahuan pada masyarakat ${ }^{6}$

\subsection{Rumusan Masalah}

1. Bagaimana penerapan hukum pidana materiil terhadap tindak pidana penyalahgunaan narkotika golongan 1 berdasarkan UndangUndang Republik Indonesia Nomor 35 Tahun 2009 tentang Narkotika ?

\footnotetext{
${ }^{4}$ Ratna WP , Aspek Pidana Penyalagunaan Narkotika, Cet. 1, LEGALITY, yogyakarta, 2017 h. 47. ${ }^{5}$ Pasal 1 angka 6 Undang-Undang Narkotika menjelaskan tentang Peredaran Gelap Narkotika dan prekusor narkotika.

${ }^{6}$ Andi Hamzah, Perkembangan Hukum Pidana Khusus, Cet. 1, PT RINEKA CIPTA, Jakarta, 1991, h. 176.
} 
2. Bagaimana pemidanaan terhadap penyalagunaan Narkotika golongan 1 pada putusan Nomor 130/Pid.Sus/2016/PN.Gsk

\subsection{Tujuan Penelitian}

1. Untuk mengetahui hukum materiil terhadap penyalagunaan narkotika golongan 1 pada putusan Nomor 130/Pid.Sus/2016/PN.Grs.

2. Untuk mengetahui bagaimana pemidanaan terhadap penyalagunaan narkotika golongan 1 pada putusan Nomor 130/Pid.Sus/2016/PN.Gr

\subsection{Manfaat Penelitian}

1. Sebagai sumbangan pemikiran bagi pengembang ilmu hukum pidana khususnya mengenai tindak pidana penyalahgunaan narkotika yang terjadi di masyarakat..

2. Sebagai tolak ukur dalam mengevakuasi bentuk perilaku-perilaku menyimpang dalam masyarakat dan menjadi sumbangan pemikiran bagi masyarakat dalam upaya memelihara dan menumbuhkan sikap tertib hukum.

\section{TINJAUAN PUSTAKA}

\subsection{Tinjauan umum tentang tindak pidana narkotika}

Tindak pidana narkotika tidak lagi dilakukan secara perseorangan, melainkan melibatkan banyak orang yang secara bersama-sama, bahkan merupakan satu sindikat yang terorganisasi dengan jaringan yang luas yang bekerja secara rapi dan sangat rahasia baik ditingkat nasional maupun internasional.

Berdasarkan hal tersebut maka upaya peningkatan pencegahan dan pemberantasan tindak pidana narkotika perlu dilakukan pembaruan terhadap Undang-Undang Nomor 22 Tahun 1997 tentang Narkotika. Hal ini juga untuk mencegah adanya kecenderungan yang semakin meningkat baik secara kuantitatif maupun kualitatif dengan korban yang meluas, terutama di kalangan anak-anak, remaja, dan generasi muda pada umumnya. penyelesaian dalam waktu yang singkat, sesuai dengan semangat yang tertera dalam Undang-Undang Nomor 35 Tahun 2009 tentang Narkotika dalam Pasal 74. Sedangkan mekanisme dari penyelesaian suatu perkara narkotika harus Untuk menimbulkan efek jera terhadap pelaku penyalahgunaan dan peredaran gelap narkotika diatur mengenai pemberatan sanksi pidana, baik dalam bentuk pidana minimum khusus, pidana penjara 20 (dua puluh) tahun, pidana penjara seumur hidup,maupun pidana mati. Pemberatan pidana tersebut dilakukan dengan mendasarkan pada golongan,jenis,ukuran,dan jumlah narkotika.

Di dalam Undang-Undang Nomor 35 Tahun 2009 Bab XV mengenai Ketentuan Pidana, beberapa pasal yang mencantumkan sanksi pidana yang menyangkut tindak pidana narkotika, antara lain Pasal 113, Pasal 114, Pasal 116, Pasal 118, Pasal 119, dan Pasal 121.

\section{METODE PENELITIAN}

\subsection{Rancangan Penelitian}

Dalam melakukan suatu penelitian hukum tidak dapat terlepas dengan pengunaan metode penelitian. Karena setiap penelitian apa saja pastilah mengunakan metode untuk menganalisa permasalahan yang diangkat.

Menurut Peter Mahmud, "penelitian hukum adalah suatu proses untuk menemukan aturan hukum, prinsip-prinsip hukum, maupun doktrindoktrin hukum guna menjawab isu hukum yang dihadapi"? 7

Metode penelitian hukum Normatif adalah prosedur penelitian ilmiah untuk menemukan kebenaran berdasarkan logika keilmuan hukum dari sisi normatifnya, Logika keilmuan yang ajeg dalam penelitian hukum normatif dibangun berdasarkan disiplin ilmiah dan cara-cara kerja

${ }^{7}$ Peter Mahmud Marzuki, penelitian hukum, Kencana Prenada Media Group, Jakarta, 2011, h. 35 . 
ilmu hukum normatif, yaitu. ilmu hukum yang objeknya hukum itu sendiri. ${ }^{8}$ Pada penelitian hukum normatif, bahan pustaka merupakan data dasar yang dalam (ilmu) penelitian digolongkan sebagai data sekunder. Data sekunder tersebut mempuyai ruang lingkup yang sangat luas, sehingga meliputi surat-surat pribadi,buku-buku harian, buku-buku, sampai pada dokumendokumen resmi yang dikeluarkan oleh pemerintah. ${ }^{9}$

\subsection{Sumber Bahan Hukum}

Bahan hukum primer yaitu bahan yang bersifat autoritatif, artinya mempunyai otoritas, bahan-bahan hukum primer terdiri dari perundang-undangan, catatan-catan resmi atau risalah dalam perbuatan perundang-undangan dan putusan-putusan hakim. ${ }^{10}$ Adapun yang menjadi bahan hukum primer dari penelitian ini adalah :

a. Undang-Undang Dasar Republik Indonesia Tahun 1945

b. Undang-Undang Republik Indonesia Nomor 35 Tahun 2009 tentang Narkotika

c. Undang-Undang Republik Indonesia Nomor 5 Tahun 1997 tentang Psikotropika

d. Peraturan Pemerintah Republik Indonesia Nomor 40 Tahun 2013 tentang Pelaksanaan Undang-Undang Nomor 35 Tahun 2009 tentang Narkotika

e. Pengaturan Presiden Republik Indonesia Nomor 23 Tahun 2010 tentang Badan Narkotika Nasional

Putusan Pengadilan Negeri Gresik yang sudah berkekuatan hukum yang tetap dengan Putusan Nomor 130/Pid.Sus/2016/PN.Gsk

8 Ibrahim, dan Johnny, Teori \& Mclode Penelitian Hukum Normatif, Bayumedia Publishing, Malang, 2005, h. 47.

${ }^{9}$ Ibid, h.24.

${ }^{10}$ Ibid, h. 185 .
Bahan hukum sekunder yaitu bahan hukum yang berupa semua publikasi tentang hukum yang bukan merupakan dokumen-dokumen resmi. Peblikasi tentang hukum meliputi buku-buku teks, kamus-kamus hukum, jurnal-jurnal hukum, dan komentar-komentar atas putusan pengadilan. ${ }^{11}$

Bahan hukum tersier adalah bahan hukum yang memberikan petunjuk atau penjelasan terhadap bahan hukum primer dan bahan hukum sekunder dengan memberikan pemahaman dan pengertian atas bahan hukum lainnya seperti kamus, jurnal, encyclopedia, dan lain-lain. Bahan hukum tersier yang digunakan dalam penelitian ini adalah kamus bahasa Indonesia, kamus hukum, dan lain-lain sebagai penunjang.

\subsection{Teknik Analisis Data}

Dalam menganalisa data, penulis menggunakan metode deskriptif analistis, yaitu suatu analisa data yang menjelaskan secara tepat kemudian dianalisa, guna memperoleh kejelasan suatu masalah, dari hasil penelitian ini menunjukan bahwa penerapan Penyalagunaan Narkotika Golongan 1 Pasal 144 ayat (1) UndangUndang Republik Indonesia Nomor 35 Tahun 2009 tentang Narkotika putusan nomor 130/Pid.Sus/2016/PN.Gsk sesuai dengan perundang-undangan yang berlaku dan dalam menjatuhkan vonis pidana, hakim telah memberikan pertimbangan-pertimbangan sesuai dengan fakta yang terungkap di persidangan baik itu pertimbangan dari segi materiil maupun formil sehingga terdakwa tidak dijatuhi sanksi pidana maksimal.

\section{HASIL PENELITIAN DAN PEMBAHASAN}

\subsection{Analisis pemidanaan}

hasil dari wawancara dengan salah satu hakim Pengadilan Negeri Tulungagung dan Beliau juga termasuk salah satu dari Majelis Hakim dalam perkara Dari pemaparan Beliau, pertimbangan hukum dalam kasus ini adalah :

\footnotetext{
${ }^{11}$ Ibid, h. 196.
} 
Nomor : 130/Pid.Sus/2016/PN.Grs ini adalah sebagai berikut :

1. Bahwa terhadap dakwaan Penuntut Umum, terdakwa dan Penasihat hukumnya telah mengerti dan tidak mengajukan eksepsi atau keberatan

2. Bahwa untuk membuktikan dakwaan penuntut umum mengajukan 3 saksi, yang memberikan kesaksian dibawah sumpah, sebagai berikut:

Saksi DWI RAHMANTO, dibawah sumpah pada pokoknya menerangkan sebagai berikut ;

- Bahwa Saksi pernah menangkap Terdakwa, karena Terdakwakedapatan membawa dan memiliki Narkoba ;

- Bahwa ketika melakukan penangkapan Saksi bersama Ipda Dian Anang selaku Kaur Bin Ops (KBO Narkoba), Aipda Andik Putro W dan Brigadir Dian Fitroh Kalista pada hari Senin, tanggal 21 Desember 2015 sekitar jam 21.30 Wib di Jln.Desa Sukorejo , Kecamatan Bungah Kabupaten Gresik

- Bahwa dasar penangkapan Terdakwa karena ada informasi dari saudara Nanang 1 (satu) minggu sebelum penangkapan ;

- Bahwa Terdakwa sempat diobservasi keberadaannya selama 1 (satu) minggu oleh saudara Nanang ;

- Bahwa saat penangkapan, Terdakwa dalam posisi perjalanan melintas dijalan Sukorejo kemudian dipepet dan ditabrak dengan saudara Andik Putro yang berboncengan dengan saudara Dian Fitroh K, dimana Terdakwa sempat diberhentikan oleh saudara Andik Putro W namun Terdakwa tidak berhenti lalu Saksi yang menabrak dibelakangnya ;
- Bahwa Terdakwa sendirian naik sepeda motor Honda Vario, saat itu

selain Terdakwa terjatuh semua anggota tim dan Saksi juga ikut terjatuh;

- Bahwa saat Saksi jatuh bersama temanteman Saksi kemudian Saksi pegang pundak Terdakwa sedangkan teman Saksi, yaitu Andik Putro Wibowo dan Dian Fitroh K yang menggeledah Terdakwa, sewaktu digeledah, Andik memlintir tangan Terdakwa dan Terdakwa sempat membuang barang sabusabunya ;

- Bahwa pada waktu itu mulut Terdakwa berdarah dan ada luka pada sebelah kanan;

- Bahwa selain Terdakwa terluka, Saksi bengkak, KBO Narkoba ada lecetnya ;

- Bahwa Terdakwa sempat digeledah badannya oleh Saksi Dian dan Andik, mulai baju sampai celana kolor dan ditemukan 1 (satu) poket shabu yang disembunyikan disebelah kanan kantong depan dalam celana

- Bahwa SOP penggeledahan adalah pemberhentian terhadap diri Terdakwa, digeledah seluruh badannya dari baju sampai celana tanpa menelanjangi Terdakwa;

- Bahwa setelah sampai di Kantor Polres 1 (satu) poket shabu tersebut ditimbang;

- Bahwa selain sabu, yang dijadikan barang bukti adala HP merk Evercross warna putih, namun Barang bukti HP diambil dirumah Terdakwa dan ketika ditangkap di TKP, HP tersebut tidak ditemukan;

- Bahwa celana Terdakwa sempat dilepas dan barang bukti ditemukan saat celana dilepas dengan jarak posisi celana yang dilepas tersebut dengan Terdakwa adalah satu meter ; 
- Bahwa awalnya sepeda motor Terdakwa dijadikan barang bukti tapi sekarang Saksi tidak tahu karena bukan wewenang Saksi namun menurut teman-teman Saksi karena ada permohonan dari keluarga Terdakwa dengan alasan rasa kemanusiaan saja karena di rumah Terdakwa tidak ada sepeda motor maka sepeda motor tersebut tidak dijadikan sebagai barang bukti ;

- Bahwa sabu tersebut sudah di tes dan hasil tes laboratorium forensic tersebut positif menurut BAP Polisi ;

- Bahwa sebelum dilakukan penangkapan sekitar jam 19.00 Wib ada percakapan antara Nanang dengan Terdakwa ;

- Bahwa Terdakwa dengan saudara Nanang janjian di pertigaan masuk kearah pejanten, dimana sekitar jam 19.00 Wib Nanang telp Terdakwa menanyakan kalau ada barang ta, kemudian Nanang ketemuan dengan Terdakwa di Indomaret Bungah, namun Terdakwa masih ambil barang di rumah dan balik lagi ke Bungah;

- Bahwa ada uang yang diserahkan Nanang ke Terdakwa sebesar Rp.250.000,-, namun saat digeledah uang tidak ada;

- Bahwa uang tersebut untuk pancingan dari saudara Nanang

- Bahwa ketika ditangkap Terdakwa sempat bilang Ya Allah mati, kemudian Terdakwa Saksi bentak dan Saksi bilang jangan sebut nama Allah

- Bahwa ketika ditangkap Terdakwa tidak memberontak dan Terdakwa diam saja ;

- Bahwa Terdakwa tidak mengatakan kalau barang tersebut sabu Terdakwa hanya mengatakan barang lama sudah satu minggu dan didapat dari saudara Agus di Surabaya ;
- Bahwa barang bukti yang berupa sabu ditunjukkan untuk difotoadalah barang yang ditemukan dilapangan ;

- Bahwa ketika pemeriksaan Terdakwa,Saksi selalu mendampingi Terdakwa ;

- Bahwa Terdakwa dalam memberikan keterangan di BAP Penyidik tersebut tanpa ada paksaan dari Penyidik dan atas kesadaran Terdakwa sendiri ;

- Bahwa tangan Terdakwa tidak dipatahkan ;

- Bahwa gambar/Foto di BAP posisinya benar;

- Bahwa posisi gambar di BAP tidak ada luka apapun, namun ada bekas luka ketika jatuh diatas mulut Terdakwa;

- Bahwa pada hari itu juga dibuat BAP Terdakwa dan diperiksa, yang memotret Terdakwa adalah bagian penyidikan dan Terdakwa mau tanda tangan dengan suka rela ;

- Bahwa Saksi membenarkan gambar di foto ini sel yang ada di Polres Gresik ;

- Bahwa tidak boleh/tidak dibenarkan membawa kamera di sel tahanan ;

- Bahwa Saksi membenarkan barang bukti yang ditunjukkan dipersidangan ;

- Terhadap keterangan Saksi, Terdakwa memberikan pendapatnya bahwa yang salah yaitu barang bukti tidak ditemukan didepan Terdakwa dan Terdakwa disuruh ngakui barang bukti kalau tidak mau Terdakwa dipukul ;

\subsection{Pertimbangan Hakim dan Kritikan Putusan Perkara Nomor 130/Pid.Sus/2016/PN.Grs.}

DariputusanNomor:130/Pid.Sus/2016/PN.Gs $\mathrm{k}$ terdakwa telah melanggar ketentuan Pasal 127 ayat (1) a UU RI Nomor 35 Tahun 2009 
Tentang Narkotika terdakwa telah terbukti menyalahgunakan Narkotika Golongan I untuk kepentingan pribadi dan secara jelas telah mengerti bahwa hal tersebut melanggar hukum.

Dari putusan tersebut hakim menjatuhkan pidana kepada terdakwa berdasarkan alasanalasan dan bukti-bukti yang konkrit sesuai dengan ketentuan Pasal 183 dan 184 Kitab Undang-Undang Hukum Acara Pidana, bahwa hakim tidak boleh menjatuhkan pidana kepada seseorang kecuali apabila sekurang- kurangnya dua alat bukti yang sah. Segala sesuatu yang berjalan dalam persidangan dimulai dari dakwaan penuntut umum, proses pembuktian melalui alat bukti, barang bukti serta kesaksian para saksi, pendapat para ahli, keterangan terdakwa, tuntutan jaksa, dan keyakinan hakim dijadikan bahan pertimbangan dalam mengambil suatu putusan.

Terdakwa dalam hal ini tidak mendapatkan putusan rehabilitasi, karena menurut majelis hakim terdakwa adalah penyalahguna narkotika bukan korban penyalahguna narkotika. Seorang penyalahguna berbeda dengan korban penyalahgun kualifikasi seorang penyalahguna narkotika disini adalah mengerti dan tahu bahwa barang tersebut (narkotika) itu dilarang namun tetap dipertahankan untuk dikonsumsi atau dipakai Putusan Hakim Nomor : 130/Pid.Sus/2016/PN.Gsk dalam Tindak Pidana Penyalahgunaan Narkotika Golongan I adalah sebagai berikut :

1. Menyatakan Terdakwa SUPRIYADI tidak terbukti secara sah dan meyakinkan bersalah melakukan tindak pidana sebagaimana dalam dakwaan primair ;

2. Membebaskan Terdakwa dari dakwaan Primair tersebut;

3. Menyatakan Terdakwa SUPRIYADI telah terbukti secara sah dan meyakinkan bersalah melakukan tindak pidana "Menguasai Narkotika Golongan I Bukan Tanaman";

4. Menjatuhkan pidana terhadap Terdakwa tersebut oleh karena itu dengan pidana penjara selama 4 (empat) tahun dan denda sejumlah Rp. 800.000.000,(Delapan ratus juta rupiah) dengan ketentuan apabila denda tersebut tidak dibayar diganti dengan pidana penjara selama 6 (enam) bulan ;

5. Menetapkan masanpenangkapan dan penahanan yang telah dijalani Terdakwa dikurangkan seluruhnya dari pidana yang dijatuhkan;

6. Menetapkanagar Terdakwa tetap ditahan;

7. Menetapkan barang bukti berupa: 1 (satu) bungkus plastik kecil berisi kristal putih berupa shabu/ metamfetamina dengan berat timbang lebih kurang 0,24 (nol koma dua puluhempat) gram berikut bungkusnya (berat netto 0,19 gram); 1 (satu) buah HP Evercoss warna putih dengan nomor 087717297000.- 1 (satu) buah celana warna hitam;dirampas untuk dimusnahkan; 1 (satu) buah draft Surat Rekomendasi nomor : Rekom/001/I/TAT/

Pm.00.00/2016/BNNK-GRS dengan Kop surat Tim Asesmen Terpadu BNN Kabupaten Gresik, 1 (satu) buah draft surat Asesmen Hukum III dengan kop surat : Badan Narkotika Nasioanl RI Kabupaten Gresik, tetap terlampir dalam berkas perkara;

Membebankan kepada Terdakwa membayar biaya perkara sebesar Rp.2.000,- (dua ribu rupiah); Dalam menetapkan putusan perkara Nomor : 130/Pid.Sus/2016/PN.Gsk hakim memiliki pertimbangan hukum yang menjadi alasan dan dasar putusan. Dengan pertimbangan berupa alat bukti sesuai dengan Pasal 184 ayat (1) KUHP (keterangan saksi, keterangan ahli, surat, petunjuk, keterangan terdakwa) dan barang bukti atas tindak pidana, serta dakwaan dan tuntutan penuntut umum dan tidak mengesampingkankebenaran formil maupun materiil selama proses persidangan.

\section{KESIMPULAN DAN SARAN}

\subsection{Kesimpulan}

Penerapan Hukum Pidana Materiil oleh Hakim terhadap tindak pidana Penyalahgunaan Narkotika Golongan I dalam Putusan Perkara Nomor 130/Pid.Sus/2016/PN.Gsk telah tepat. Jaksa Penuntut Umum menggunakan 2 (dua) dakwaan, yaitu: Primair Pasal 112 Ayat (1) UU. RI. No 35 tahun 2009 tentang Narkotika Jo Pasal

132 (1) UU. RI. No 35 tahun 2009 tentang Narkotika , dan Subsidiair Pasal 127 Ayat (1) huruf a UU. RI. No 35 tahun 2009 tentang Narkotika. Diantara unsur-unsur kedua Pasal yang didakwakan oleh Jaksa Penuntut Umum 
tersebut, yang terbukti secara sah dan meyakinkan bersalah adalah Pasal 127 Ayat (1) huruf a UU. RI. No 35 tahun 2009 tentang Narkotika. Dimana antara perbuatan dan unsur-unsur Pasal saling mencocoki.

Pertimbanga hukum oleh Hakim terhadap tindak pidana Penyalahgunaan Narkotika Golongan I dalam menjatuhkan pemidanaan telah tepat karena Hakim dalam perkara Nomor 130/Pid.Sus/2016/PN.Gsk.menjatuhkan pemidanaan berdasarkan keterangan saksi, keterangan terdakwa, dan alat bukti surat yang menurut Pasal 184 KUHAP merupakan alat bukti yang sah. Selanjutnya alat-alat bukti tersebut mendukung fakta-fakta yang terungkap dalam persidangan yang meyakinkan hakim bahwa tindak pidana Penyalahgunaan Narkotika Golongan I benar- benar terjadi dan terdakwalah yang bersalah melakukannya Putusan Hakim Nomor: 130/Pid.Sus/2016/PN.Gsk dalam Tindak Pidana Penyalahgunaan Narkotika Golongan I adalah sebagai berikut :

1. Menyatakan Terdakwa SUPRIYADI tidak terbukti secara sah dan meyakinkan bersalah melakukan tindak pidana sebagaimana dalam dakwaan primair ;

2. Membebaskan Terdakwa dari dakwaan Primair tersebut;

3. Menyatakan Terdakwa SUPRIYADI telah terbukti secara sah dan meyakinkan bersalah melakukan tindak pidana "Menguasai Narkotika Golongan I Bukan Tanaman" ;

4. Menjatuhkan pidana terhadap Terdakwa tersebut oleh karena itu dengan pidana penjara selama 4(empat) tahun dan denda sejumlah Rp.800.000.000,- (Delapan ratus juta rupiah) dengan ketentuan apabila denda tersebut tidak dibayar diganti dengan pidana penjara selama 6 (enam) bulan ;

5. Menetapkan masanpenangkapan dan penahanan yang telah dijalani Terdakwa dikurangkan seluruhnya dari pidana yang dijatuhkan;

6. Menetapkan agar Terdakwa tetap ditahan;

7. Menetapkan barang bukti berupa: 1 (satu) bungkus plastik kecil berisi kristal putih berupa shabu/ metamfetamina dengan berat timbang lebih kurang 0,24 (nol koma dua puluhempat) gram berikut bungkusnya (berat netto 0,19 gram); 1 (satu) buah HP Evercoss warna putih dengan nomor 087717297000.- 1 (satu) buah celana warna hitam;dirampas untuk dimusnahkan; 1 (satu) buah draft Surat Rekomendasi nomor : Rekom/001/I/TAT/ Pm.00.00/2016/BNNK-GRS dengan Kop surat Tim Asesmen Terpadu BNN Kabupaten Gresik, 1 (satu) buah draft surat Asesmen Hukum III dengan kop surat : Badan Narkotika Nasioanl RI Kabupaten Gresik, tetap terlampir dalam berkas perkara;

8. Membebankan kepada Terdakwa membayar biaya perkara sebesar Rp.2.000,- (dua ribu rupiah); Dalam menetapkan putusan perkara Nomor : 130/Pid.Sus/2016/PN.Gsk hakim memiliki pertimbangan hukum yang menjadi alasan dan dasar putusan. Dengan pertimbangan berupa alat bukti sesuai dengan Pasal 184 ayat (1) KUHP (keterangan saksi, keterangan ahli, surat, petunjuk, keterangan terdakwa) dan barang bukti atas tindak pidana, serta dakwaan dan tuntutan penuntut umum 
dan tidak mengesampingkan kebenaran formil maupun materiil selama proses persidangan.

\subsection{Saran}

1. Bagi penegak hukum (Hakim) Sebagai aparat penegak hukum yang dihormati dan disegani yang dianggap mampu sebagai penegak keadilan bagi masyarakat pencari keadilan. Dalam memberikan putusan terhadap tindak pidana khususnya dalam tindak pidana penyalahgunaan narkotika diharapkan mampu menerapkan keadilan berdasarkan asas-asas hukum pidana, ketentuan undang-undang yang berlaku, serta fakta-fakta hukum selama proses persidangan berlangsungtanpa mengesampingkan kebenaran materiil maupun formil.

Berat dan ringan suatu putusan yang ditetapkan oleh hakim harus memiliki tujuan sebagaimana yang berlaku sebagai tujuan pemberlakuan sanksi tindak pidana. Seorang hakim juga harus dibekali dengan kemampuan spiritual agar selalu mendekatkan diri kepada Yang Maha Pencipta alam semesta ini, dan menerapkan prinsip bahwa keadilan hanya milik-Nya dan hakim hanya sebagai perantara dalam menentukan keadilan dimuka bumi ini.

2. Bagi mahasiswa Hukum Sebagai akademisi calon-calon penegak hukum dituntut harus mampu dan mengerti hukum tidak hanya secara teori namun parkteknya dalam beracara pidana di Pengadilan. Teruslah menciptakan terobosan-terobosan karya yang mampu membantu dalam penegakan hukum dan keadilan di Indonesia dengan kegigihan dan keuletan sebagai akademisi, karena dengan kegigihan dan keuletan kita mampu merasakan manisnya sebuah perjuangan.

\section{DAFTAR BACAAN}

\section{Buku}

Teguh Sulistina, Hukum Pidana : Horizon Baru Pasca Reformasi, penerbit PT RajaGrafindoPersada, Jakarta, 2012.

Muhammad Yamin, Tindak Pidana Khusus, Pustaka setia, Bandung, 2009.

Sujono, komentar \& Pembahasan UndangUndang Nomor 35 Tahun 2009 tentang Narkotika, Sinar Grafika, Jakarta, 2011.

Ratna WP, aspek pidana penyalagunaan narkotika, LEGALITY, Jogyakarta, 2017.

Andi Hamzah, Perkembangan Hukum Pidana

Khusus, PT RINEKA CIPTA, Jakarta, 1991.

Julian Lisa FR, Narkoba,Psikotropika dan Gangguan Jiwa, Nuha Medika, Jakarta, 2013.

Ibrahim, Teori \& Mclode Penelitian Hukum Normatif, Bayumedia Publishing, Malang, 2005.

H Bunggink JJ, Refleksi Tentang Hukum, PT Citra Aditya Bakti, Bandung, 1999.

Bernad Arief Sidhartha, Refleksi Tentang Setruktur Hukum, MANDAR MAJU, Bandung, 2009.

Marzuki Peter Mahmud, Penelitian Hukum, Prenadamedia Group, Jakarta, 2016.

Yudha Bhakti Ardhiwisata, Penafsiran dan Konstruksi Hukum, alumni, Bandung, 2000.

Bambang Sutiyoso, Metode Penemuan Hukum Upaya Mewujudkan Hukum Yang Pasti Dan Berkeadilan, UII Press, Yogyakarta, 2006.

Adami Chazawi, Stelsel Pidana, Tindak

Pidana, Teori-teori Pemidanaan \& Batas Berlakunya Hukum Pidana, RajaGrafindo Persada, Jakarta, 2002.

Amir Ilyas, Asas-asas Hukum Pidana Memahami Tindak Pidana Dan Pertanggungjawaban Pidana Sebagai Syarat 
Pemidanaan, Rangkang Education Yogyakarta \&

PuKAP Indonesia Makassar, 2012.

Andi Hamzah, Asas-asas Hukum Pidana, Renika Cipta, Jakarta, 1994.

Efendi, Hukum Pidana Indonesia, PT. Refika Aditama, Bandung, 2011.

Hari Sasangka, Narkotika dan Psikotropika dalam Hukum Pidana, Mandar Maju, Bandung, 2003.

Leden Marpung, Asas Teori Praktik Hukum Pidana, Sinar Grafika Jakarta, 2006.

Moeljatno, Asas-asas Hukum Pidana, Rineka Cipta, Jakarta, 2009.

Moh Taufik Makarao, Tindak Pidana Narkotika, Ghalia Indonesia, Jakarta, 2003.

PAF Lamintang, Dasar-dasar Hukum Pidana Indonesia, PT.Citra Aditya Bakti, Bandung, 1984.

Zainal Abidin Farid, Hukum Pidana I, Sinar Grafika, Jakarta, 2007.

Andi Hamzah, Hukum Acara Pidana Indonesia, sinar grafika, Jakarta, 2014.

Syarif Mappiasse, logika hukum pertimbangan putusan hakim, Prenadamedia Group, Jakarta, 2014.

Andi Hamzah, Hukum Acara Pidana Indonesia, Jakarta, Sinar Grafika, 1996.

Lilik Mulyadi, Kompilasi Hukum Pidana Dalam Perspektif Teoritis dan Praktik Peradilan, Mandar Maju, Bandung, 2010.

Rusli Muhammad, Hukum Acara Pidana Kontemporer, Bandung, PT Citra Aditya Bakti, 2007.

\section{Perundang-Undangan}

Undang-Undang Dasar Republik Indonesia Tahun 1945.

Undang-Undang Republik Indonesia Nomor 35 Tahun 2009 Tentang Narkotika.
Undang-Undang Republik Indonesia Nomor 5 Tahun 1997 Tentang Psikotropika.

Peraturan Pemerintah Republik Indonesia nomor 40 Tahun 2013 tentang

Pelaksanaan Undang-Undang Nomor 35 Tahun 2009 Tentang Narkotika.

Pengaturan Presiden Republik Indonesia Nomor 23 Tahun 2010 Tentang Badan Narkotika Nasional.

\section{Jurnal}

Sri Purwatiningsih, 'Penyalagunaan Narkoba Di Indonesia', Jurnal Populasi Universitas Gajah Mada, Vol 12, No 1, 2001

Sudikno Mertokusumo, Hukum Acara Perdata Indonesia, Yogyakarta, Universitas Atma Jaya Yogyakarta, 2010.

\section{Kamus}

Salim, Peter, \& Yenny Salim, Kamus Bahasa Indonesia Kontemporer, Modern English Press, Jakarta, 1991. 
